\title{
$621.436-222: 669.268$
}

\section{ディーゼル機関のクロムめっきシリンダ*}

\section{1.まえがき}

いかに性能のよいディーゼル機関でも，その性能を 長時間持続できなければ, 実用機関として適格とはい えない.しかも，機関は常に単位シリンダ容積あたり の出力増加, か動摔の増大および粗悪燃料の使用など の要望に追われている. 機関性能の耐久性に最も大き な影響を及ぼすのはシリンダの摩耗で，その低減対策 は常に関係者の大きな関心事になっている，ところが シリンダ摩耗にはシリンダおよびピストンリングの材 質をはじめ表面温度, 接触圧力, ピストン速度, リン グ形状など機関構造や使用燃料，潤滑油および運転条 件などいくたの要素が複雑に関係しているので，その 解決はきわめて困難である. 従来多くの関係者によ。 てこの問題が種々の面から研究されてきているが，そ れはあくまで経済的で取扱上煩雑なことがなく，いか なる使用条件でも効果があることが望ましい：これら の点でクロムめっきシリンダは最も有望なものの一つ で, 事実多くの分野で好結果を納めている.

シリンダのクロムめっきは, 1931 年オランダの H. Van der Horst が着手したのが始まりで(1)，当時イギ リスの Ricard 研究所で実験された. 第二次大戦中 アメリカ海軍が同氏を招き，まず潜水艦抢よび上陸用 舟艇のディーゼル機関シリンダに，さらには航空発動 機および鉄道用ディーゼル機関などのシリンダにクロ ムめっきを採用してから，クロムめっきシリンダは本 格的に実用されるようになった. わが国でのクロムめ っきシリンダは, 第二次大戦中航空発動機および戦車 用ディーゼル機関で実験され，いずれも信頼性が十分 でなく実用されずに終わっていたが，1949 年水産庁 漁船研究室で改めて研究が始められ, 以来諸所で盛ん に試作実験され，小形シリンダ機関にそして逐次，中. 大形シリンダのディーゼル機関に実用されるに至っ た. 以上のよらにクロムめっきシリンダについての知 見も多少古くなった観があるが，すでに得られている 結果の概要をとりまとめてみた.

* 原稿受付 昭和 42 年 1 月 25 日.

** 正貝, 神奈川大学工学部 (横捠市神奈川区六角橋)。

*** 正員, 水産庁生産部.
清 水三㽎 ${ }^{* *}$, 草間喜代松***

\section{2. シリンダ材としてのクロムめっき}

シリンダの摩耗を防止するにはまずしゅう動面の固 体接触を少なくすることが必要であるが，ピストンの 往復運動の速度が零になった瞬間油膜は切れやすく, しかも上死点位置付近では温度が高いため油の粘度は 低下し，またガス圧が高いためリングとの接触圧力む 高いなどの理由から油膜はいっそう切れやすい．した がって, シリンダ材は多少固体接触点があっても摩耗 の少ないことが必要である.めっきクロムはかたさが 高いのでアブレシブ摩耗には有利である。また，クロ 厶は摩擦係数が低く溶融点, 融解潜熱が高いうえ, そ の表面は常にち密な酸化膜でおおおれているので，鉄 と溶着摩耗を起こしにくいと考えられる.

ディーゼル機関の然料にはいおう分が含まれてお り，これが燃焼して $\mathrm{SO}_{2}$ あるいは $\mathrm{SO}_{3}$ になる. $\mathrm{SO}_{3}$ は 燃焼ガス中の水蒸気とともにシリンダ壁にふれて凝縮 し硫酸を生成する. 生た燃料の不完全然焼によって各 種有機酸が生成する．これらがシリンダ内壁面を腐食 し, 摩耗を著しく促進するので, シリンダ材は耐食性 が高いことが必要である.この点では，クロムは塩酸 および塩素を発生する薬品以外には耐食性がすぐれて いるといわれているので，十分役立つと考えられる.

しかし, 光沢あるクロムめっき表面には油保持性が なく, 油の飛まつがかかってもころがり落ちてしまう ので, 特にトランクピストン形機関ではスカッフィン グを起こす危険がある. 事寒戦時中の実験での失敗は ここにあったのである. 従来シリンダ材としては鋳鉄 が一般に使用されているが，これは鋳鉄に含まれる黒 鉛の減摩作用とその部分の油保持性によるものと考え られる.したがって，クロムめっき表面にも鋳鉄のは だにならって油保持性を付与すればよいわけである.

めっきクロムに油保持性を付与する最も簡単で一般 的な方法は逆電処理によるもので，その過程はつぎの ように説明される.すなわち,クロムの電気めっき層 は多量の水素を含み，それがめっき後放出されるので クロムめっき層は収縮する.クロム層にはそのための 応力があり，顕微鏡的みぞまたは穴が自然にできる. この応力のあるクロム層表面に逆電流をかけると, ク 
口ム層表面も全面的にわずかに溶けるが，おもに応力 の高い部分の順に溶解され肉眼的みぞまたは穴が発生 する.この方法によって，大別してチャンネルタイプ （図 1）とポケットタイプ（図 2）の2種が得られる.

このほか, 水玉模様にエッチングしたもの（図 3), 機械的に素地にへこみをつけてからめっきを施すナー リングタイプ（図 4）などがある，逆電処理によるポ ーラス層の深さはホーニング後 $0.05 \mathrm{~mm}$ 程度である が, 後者は任意の深さが得られる利点がある.

\section{3. クロムめっき施工法}

$3 \cdot 1$ 施工法の概要 まず，シリンダ内面をめっき 厚さを加えた寸法にホーニング仕上げし，簡単に脱脂 してから，めっきを施さない部分を絶縁物で被覆す る.また二サイクル機関シリンダの吸排気孔のような 部分には理め金を施す。つぎにと粒あるいは切り粉な

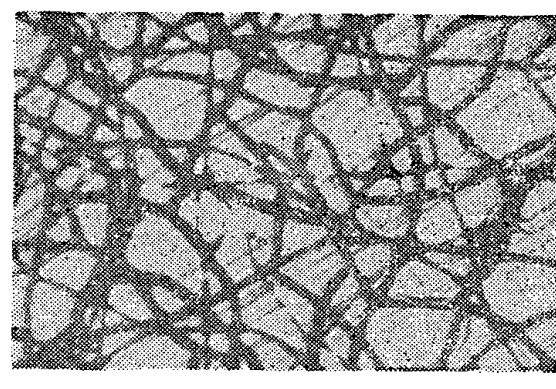

(a) 表 面 $\times 50 \times \frac{3}{4}$ 図1チ十ンネルタイプ

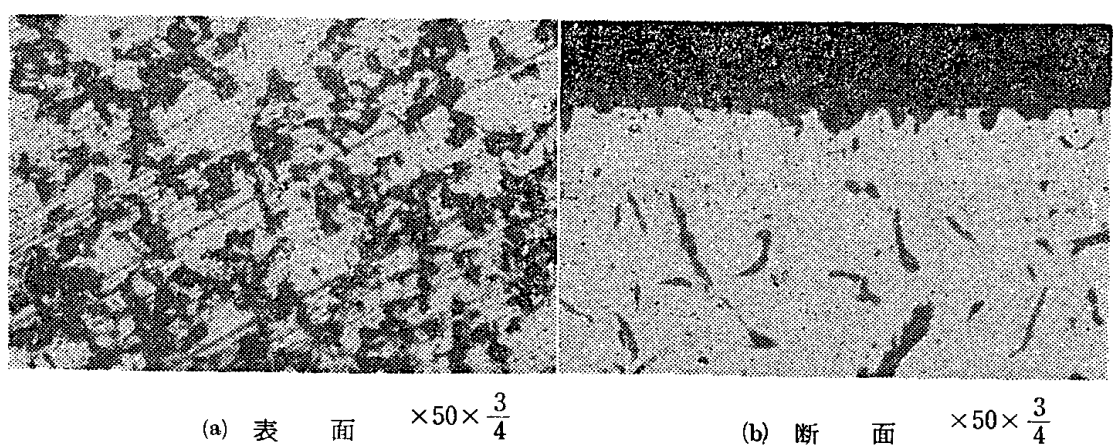

図 2 ポケットタイプ
どの除去拉よび脱脂を入念に行なってから，ジグに取 付け，電極をシリンダと同心の位置に固定する。これ をアルカリ電解洗浄そうに入れ，シリンダを陽極とし て電流を通じ，鋳鉄のグラファイトにしみ込んでいる 油や表面に吸着している油などを取除く。この処理が 終わってから,シリンダおよび電極をよく洗浄し，め っきそうに入れる．まず金属組織面を露出させクロム の密着を良好にするためごく短時間シリンダの陽極処 理を行なってから，シリンダを陰極としてめっきを 開始する. 使用される標準めっき液は $\mathrm{CrO}_{3} 250 \mathrm{~g} / l$, $\mathrm{H}_{2} \mathrm{SO}_{4} 2.5 \mathrm{~g} / l$ で, $50^{\circ} \mathrm{C} 50 \mathrm{~A} / \mathrm{dm}^{2}$ が標準めっき条件 である.めっき後油保持性をもたせるため逆電処理を 施し, シリンダをめっき液から取出しジグをはずして 水洗, 乾燥を行ない, ホーニング仕上げする. ホーニ ング仕上げ後めっき面にクロム粉やと石粉が残らない ように十分清掃する.

$3 \cdot 2$ めっき施工上の注意 シリ ンダのクロムめっきを施す上で注意 すべき点は，第一に正確なめっきを することである. まずシリンダ各部 のめっき層にへん肉がないようにす るため電極は機械仕上げをし，シリ ンダと同心に電極が固定されるよう にジグをくふうする必要がある。ま たシリンダの仕上げ寸法は $\mathrm{H}_{7}$ (JIS B 0401)程度が要求され，しかもこの 寸法に仕上げられたときシリンダ表 面の多孔度が計画值になることが必 要である，厚くめっきしすぎたもの は，ホーニングでの修正に時間がか かるのでむしろやり㨁したほうが早 いまた逆電処理をしてからの修正 量が多いと多孔度が貧弱になってし まう。したがって，シリンダごとに 寸法測定を行なってめっきすべき厚 さを決定し，めっき条件から導きだ されるめっき速度によ ってめっき時間を決 め, めっき条件および 時間を䈣密に遂行する ことが肝要である.め っきすべき厚さは仕上 がりの厚さにホーニン グしろおよび逆電処理 による減量をも加算す
る要がある. ホーニン

昭和 42 年 6 月 
グしろは $6 / 100 \mathrm{~mm}$ (直径) 以下が適当で，この程度 のホーニングによってもろい表皮を削除することがで きる. ホーニングに使用するといしはホワイトアラン ダムといし(JIS R 6111 の 4 A) のほうがカーボラン ダム系といしより切味が良い。最終仕上げには 600 番 以上のといし（JIS R 6001 の $24 \mu$ 以下）を使用しで きるだけ平滑に仕上げることが必要である.

$3 \cdot 3$ クロムめっきシリンダのあり方 クロムめっ き層の物理的, 化学的および機械的性質は電解液組成 および温度, 電流密度などめっき条件により広範囲に 変化する(2). またこれにつれてポーラスの発生形態も 変化する(3). どんなめっき層および仕上げ状態がディ 一ゼル機関のシリンダとして最も適しているか，小形 ディーゼル機関を用いて実験した結果(4)について述べ る.

供試機関はシリンダ径 $110 \mathrm{~mm}$ の立て形単シリンダ 予燃焼室付ディーゼル機関 8 PS $900 \mathrm{rpm}$ である. 無負荷500 rpm で 20 時間すり合わせ運転を行なった 後, 定格出力で運転し, 100 時間ごとに分解, 計測, 清掃，更油を行ない，これを 1 シリンダについて 5 7 回繰返した. 使用燃料はB重油, 潤滑油は 30 番モ 一タ油である.

クロムめっきシリンダの初期摩耗期間およびその間 の摩耗量は仕上げあらさによって異なり，これらの関 係は図 5 のようになる，すなわち，良好な仕上げ面ほ ど初期摩耗期間は短く，またその間の摩耗量も少な い.したがって, クロムめっきシリンダの耐摩耗性の 向上および寿命の延長をはかるためには極力鏡面に近 い良好な仕上げを行ならことが肝要で，あらさは $1 \mu$ 以下を基準とすべきである.

また定常摩耗率とクロムめっきのかたさの関係を抽 出して図示すると図 6 のようになる。 すなわちク口ム めっきのかたさが高いほど摩耗率が低減する傾向にあ る. $H_{V}(25 \mathrm{~g}) 1000$ 以上にすることが望ましい. 図 中一点だけとび離れているのはつぎに述べるように多 孔度不足によるものと考えられる。

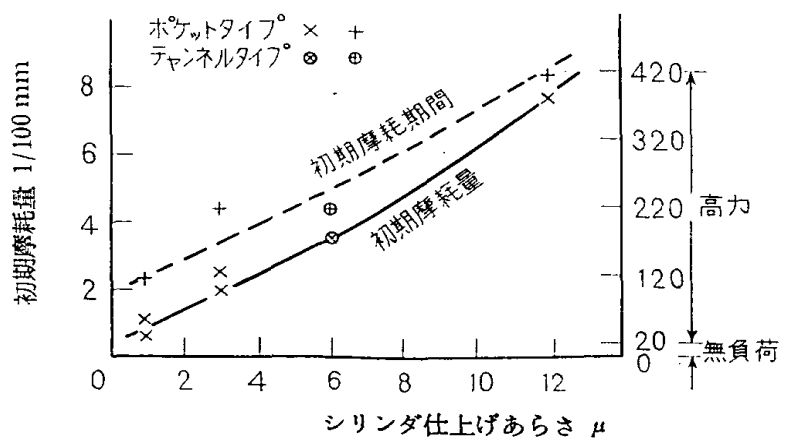

図 5 初期摩耗におよばす仕上げあらさの影響
当初のめっき層の多孔度とシリンダ定常摩耗率の関 係は図 7 のようである. 運転時間が経過するにつれて シリンダ上部の多孔度は漸次低減するが，本実験の範 囲では定常摩耗率には影響しないと判断される.同 図より本実験では多孔度 $20 \%$ 以上必要なことがわか る.しかし同図に併記したように多孔度がふえるにつ れて潤滑油消費量が増大する傾向があるので，この面 から多孔度の上限が制限されることになり，本実験で は $40 \%$ くらいが上限と考えられる.なおこの結果は 主としてポケットタイプについてのものであるが，摩 耗率はチャンネルタイプと大差ない. しかしチャンネ ルタイプでは潤滑油消費量が多くなるので, ポーラス 層の形式と多孔度とは組合せて考えるべきである. 潤 滑油消費量の多い小形シリンダ高速回転機関ではポケ ットタイプ少ない多孔度が適して招り, 逆に大形シリ ンダ低速回転機関では多孔度は多くチャンネルタイプ のほうが適している.一般に使用される多孔度は 10〜 $40 \%$ の範囲である.

なおリングの初期摩耗はいずれも 20 時間の無負荷 すり合わせ運転ではだいたい完了しているようである が, リングの初期摩耗量はやはりシリンダの仕上げあ らさが極端に悪い場合および多孔度の多すぎる場合に は大きい．またリングの平均重量摩耗率は図 8 に示す ようにシリンダの定常摩耗率とほぼ比例関係にある.

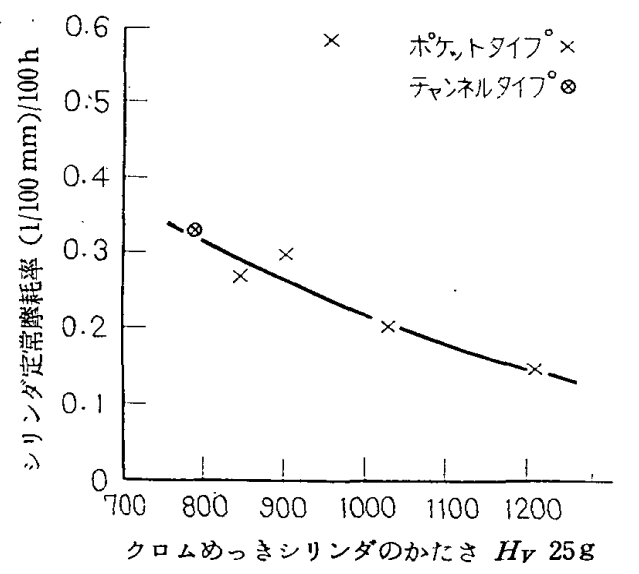

図 6 クロムめっきシリンダのかたさと摩耗率

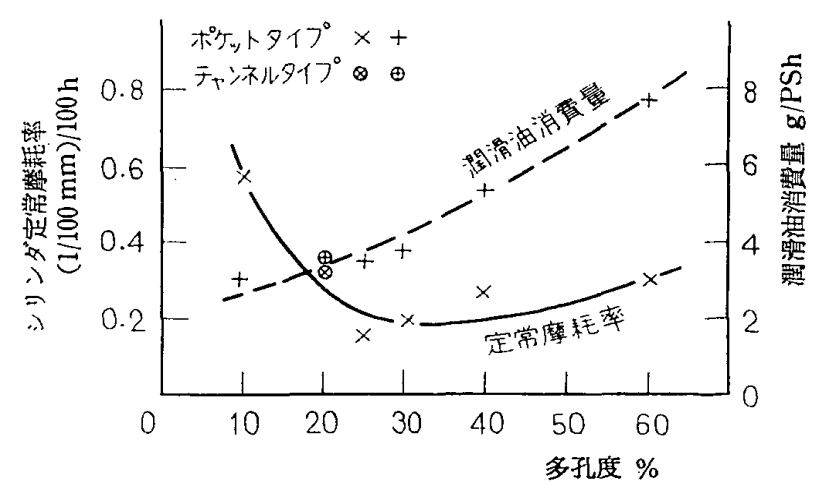

図 7 クロムめっきシリンダ多孔度の影響 
クロムめうきシリンダの信頼性に関してめっきの密 着度が繋念されるが，標準めっき液で標準めっき条件 付近での密着为の相違は少ない(5). めっき層のはく離 はしばしば経験したところであるが，いずれも前処理 不完全あるい恃停電などによる不完全なめっきによる ものである.

3·4 めっき厚さ めっき厚さを決めるには寿命を どのくらいにするかによって次式で求められる.

$$
t=\frac{1}{2} \cdot \frac{\alpha_{c}}{\alpha} R \beta
$$

ただし $t$ : シリンダ内径に対するめっき厚さ $\%, \alpha$ : 普通シリンダの摩耗率, $\alpha_{c}:$ クロムめっきシリンダの 摩耗率 ( $\alpha$. と同じ単位とす), $R$ : 寿命比, クロムめつ きシリンダの耐用運転時間の普通シリンダのそれに対 する比, $\beta$ : 普通シリンダの摩耗許容寸度のシリンダ 内径に対する割合，\%。

たとえば $\beta=0.6 \%$ とすれば

$$
t=0.3 \frac{\alpha_{c}}{\alpha} R
$$

となる. 通常 $t$ はシリンダ内径の $0.1 \%$ が基準とされ ている. クロムめっきシリンダはめっき摩滅箇所が現 われても $\beta$ と同程度まで支障なく使用できるが，再め っきするには厚いめっきをしなければならないので， むしろ経済的にはめっき摩滅部発見前に再めっきする ほうが得策である. $\alpha_{c} / \alpha$ は後述するように実用状態 では大略 1/10・であるので， $0.1 \%$ のめっき厚さでは $R$ は 3.3 となる.

\section{4.クロムめっきシリンダの耐摩耗性}

$\alpha_{c} / \alpha$ について, まず前述の実験室機関で得られた 結果を図 9 に示す. すなわち, クロムめっきシリンダ は FC 23 鋳鉄シリンダに対して 1/49 の定常摩耗率,

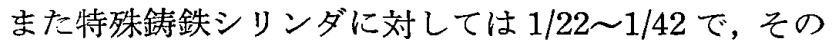
耐摩耗性はきわめてすぐれていることが確認された.

実用されている状態での $\alpha_{c} / \alpha$ は, 前記実験室機関

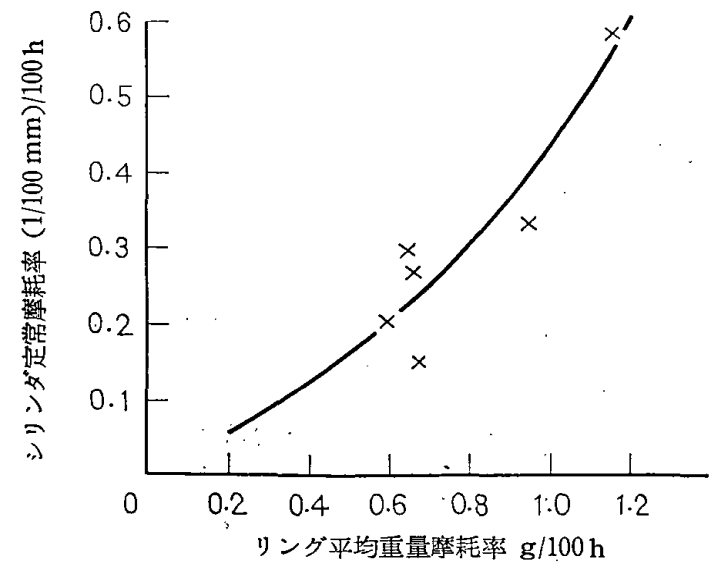

図 8 シリンダとリングの摩耗関係
と同形機関 (A重油, モータ油使用) では(6)，ク口ムめ っきシリンダの摩耗率が $\frac{0.6}{100} \sim \frac{1.8}{100}$ 平均 $\frac{1.1}{100} \mathrm{~mm} /$ 1000 h で, $1 / 11$ と一応クロムめっきシリンダの優秀 なことは認められたが，実験室における結果ほどでは なかった.これは実験室においては 100 時間ごとに閵 滑油を更新していたのに対し，奏用試験の場合には交 換時間が長かったため (300 時間程度), 潤滑油の污 損による影響が大きかったものと考えられる.このこ とについては後述する.

250〜260 および $430 \mathrm{~mm}$ のシリンダでは, 比較しら るクロムめっきシリンダの摩耗率は $\frac{0.3}{100} \sim \frac{1.1}{100} \mathrm{~mm} /$ $1000 \mathrm{~h}$ に対し普通シリンダの場合には $\frac{7.2}{100} \sim \frac{11}{100}$ $\mathrm{mm} / 1000 \mathrm{~h}$ で, $\alpha_{c} / \alpha$ は $1 / 10 \sim 1 / 20$ である.

また $500 \mathrm{~mm}$ 以上の三サイクルディーゼル機関のシ リンダについて求められた $\alpha_{c} / \alpha^{(7)(8)(9)}$ は，だいたい 1/3〜1/10である.

以上のように実用状態での $\alpha_{c} / \alpha$ は大略 $1 / 10$ という ことができる.ただし二サイクル機関では $1 / 3 \sim 1 / 4$ と いうものが大半を占めているが，これはクロムめっき の差というよりむしろしゅう動回数が少ないのですり 合わせに時間がかかるためと, 以下に述べる腐食摩耗 の影響と考えられ，少なくとも $1 / 10$ 程度に改善されう るものと判断される.

\section{5. クロムめっきシリンダの問題点}

すでに周知のことであるが，クロムめっきシリンダ を使用する上で避けるべきことはクロムめっきリング の使用である.

クロムめっきシリンダの表面に白はんが発生するこ とがある.これは硫酸による腐食のために生ずる.ク

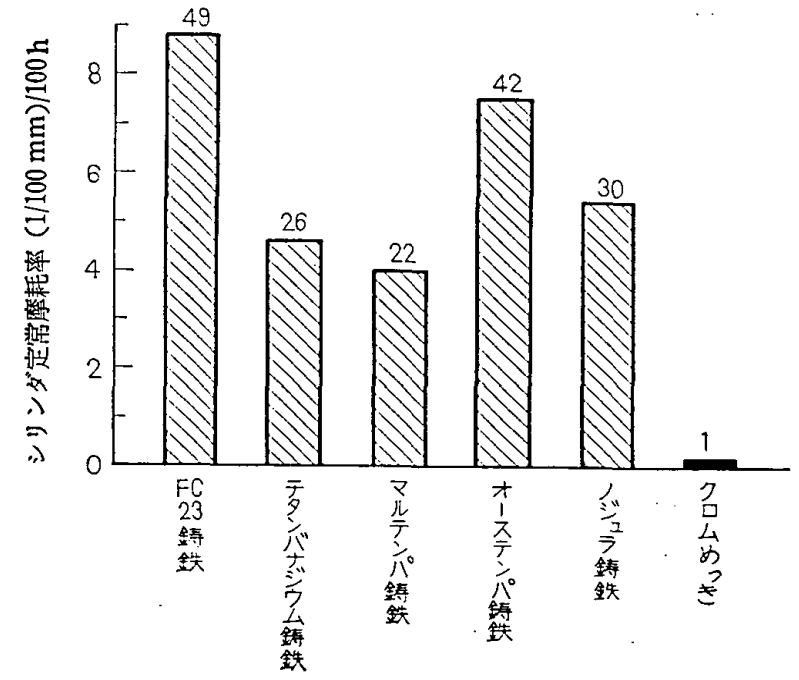

図 9 各種材質シリンダの定常摩耗率の比較 (鋳鉄シリンダに対してはクロムめ。 きリングを使用す） 
ロムは普通硫酸には侵されることはないが，摩耗によ って現われた新開面が侵されるものと解釈される. い つたん腐食の始まった箅所は引続いて腐食が進行し白 はんとなる.小形シリンダ機関ではほとんど白はんを 見ることはないが，これはシリンダ表面の油膜が比較 的よく形成されるため摩耗が軽微で, またつぎのしゅ う動により修復されるためであろう. 反対に中：大形 シリンダ機関では一様な油膜の形成が困難な上，腐食 性ガスにさらされている時間が長いこと，および粗悪 然料を使う場合が多いことなどにより白はんの発生が 多いと考えられる. しかし白はんが認められなくても 硫酸クロムが検出されることがあり(10),トランクピス トン形機関の例では図 10(11) のように潤滑油中の遊離 硫酸分が増すほど腐食摩耗の割合が多くなりこれに つれて摩耗率も増大する．前述したような潤滑油交換 時間が長い場合当然シリンダ摩耗に悪影響を及ぼす。

白はんおよび腐食摩耗の防止対策としては, 然料中 のいおう分の燃焼量に見合ったアルカリ分をシリンダ 壁面に供給してやるのが効果的である(12). また, 特に 大形シリンダの場合には，すり合わせに時間がかかる ので,この期間中潤滑油注油量を 30〜 50\% 増してや ることも効果がある.

\section{6. クロムめっきシリンダの経済価值}

クロムめっきシリンダは鋳鉄シリンダに比して摩耗 が少ないためつぎの利点がある。

6.1 シリンダ交換数量が少ない $260 \mathrm{~mm} 6$ シリ ンダ機関の例をとると, 多数の実用成績では鋳鉄シリ ンダとクロムめっきシリンダの摩耗による寿命比は 1:3〜5（平均 1:4）の範囲で, クロムめっきシリン

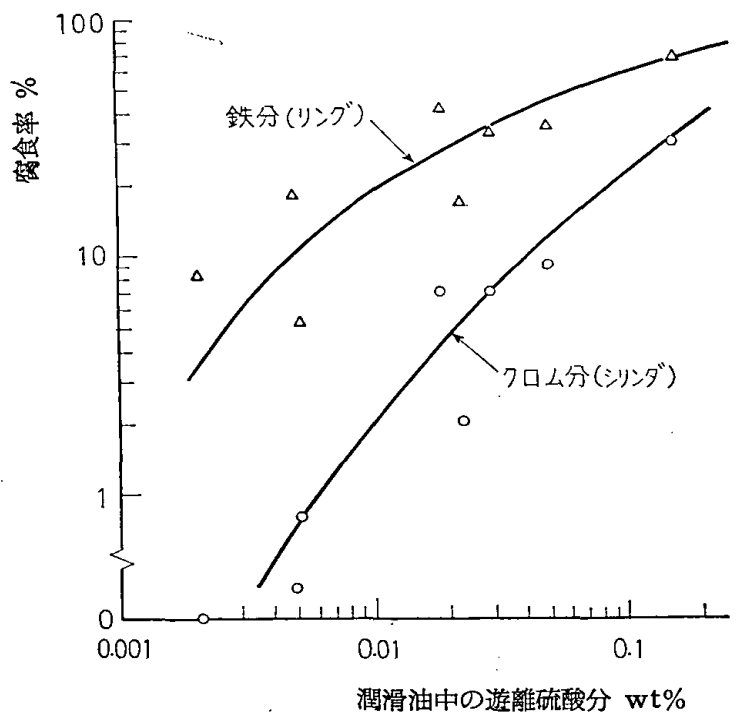

図 10 潤滑油中の遊離硫酸分に対する クロムおよび鉄の窝食率
ダの寿命までの間におけるライナ交換による経費を鋳 鉄シリンダの場合と比較すると表 1 のとおりである.

すなわち，クロムめっきシリンダの探用により約 $50 \%$ の経費節約になる.このほかリングの交換 数量 も少なくこのための経費む節約できる.

$6 \cdot 2$ 機関性能が良好に保持できる クロムめっき シリンダと鋳鉄シリンダの許容摩耗量はそれぞれシリ ンダ直径の $0.2 \%$ および $0.6 \%$ くらいである. 前例の $260 \mathrm{~mm}$ シリンダ機関についてシリンダ摩耗経過を模 型的に示すと図 11 のようになる.すなわち，クロム めっきシリンダの場合の全期閒の摩耗量は平均 $0.1 \%$ であるのに対し，鋳鉄シリンダの場合は平均 $0.3 \%$ で ある.このようにクロムめっきシリンダは摩耗量の少 ない状態すなわちリングギャップの少ない状態で運転 され，リングの気密および油密作用は良好に保たれる ため, 一般に燃料消費量は約 $5 \%$ ，潤滑油消費量は約 $60 \%$ 低減している.

$6 \cdot 3$ 機関のか動率が向上するクロムめっきシリ ンダを採用することによって，シリンダおよびリング の交換修理のための延べ日数を短縮し, か動率を向上 しうるので事業経営上非常に有利である.

6.4 機関取扱者の労働軽減になる 漁船, 船舶の 場合, シリンダあるいはリングの交換は入港時荷物の 陸あげ，積込み期間中に極力遂行しようとするため関 係央組員は休む睱むないのに対し，クロムめっきシリ ンダの採用によってこの作業をはぶくことができる. また機関性能が良好に保たれるため各部の手入れは少 なくまた簡単になる．近時人員不足から労働軽減が強

表 1

\begin{tabular}{|c|c|c|}
\hline & 鈜鉄シリンダ & クロムめっきシリンダ \\
\hline 所要シリンダライナ数 & $6 \times 4$ 本 & 6本 \\
\hline $\begin{array}{l}\text { 椞要シリンダライナ価 } \\
\text { 格 }\end{array}$ & 96 万円 & 48 万円 \\
\hline 分 解 組 立 回 数 & 4 回 & 1 回 \\
\hline 分 解 組 立費 用 & 20 万円 & 5 万円 \\
\hline 計 & 116 万円 & 53 万円 \\
\hline
\end{tabular}

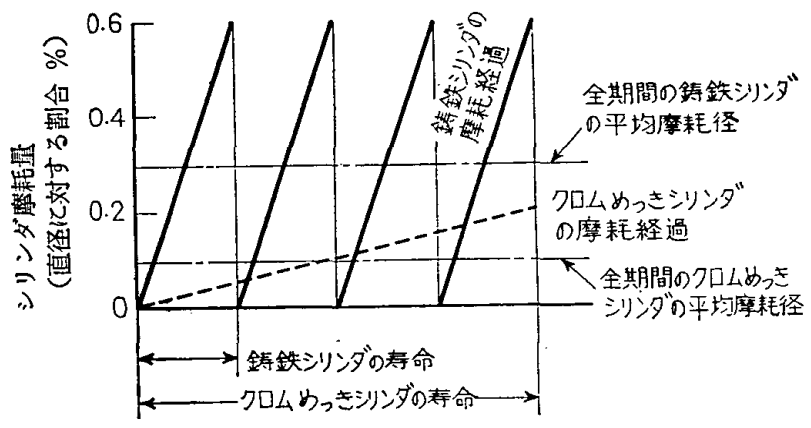

図 11 シリンダ摩耗経過模型 
く要望されているので,これによる利益は簡単に計算 できないが最も重要なものである.

\section{7.あとがき}

近年漁業あるいは海運界の合理化の進展に伴うて， 穖関の長期無解放が叫ばれてきた.この点高アルカリ 性シリンダ油の出現によって飛躍的な延長がなされて いるが,今後はクロムめっきシリンダの採用にまつと ころが大きいと信ずる.

\section{文献}

(1) H. Van der Horst, SAE Philadelphia Section Mee- ting, (1940-4).

（2）たとえば, P. Morisset, J.W. Oswald, C.R. Draper, \& R. Pinner, Chromium Plating, (1954), 138. Robert Draper.

（3）たとえば, J.M. A. Van der Horst, 内然機関，2-13 (昭 38-7), 107.

（4）清水・沙汃, 漁船研究技報，3（昭 27-3)，87；4（昭 28-12）， 49.

（5）紙野，日立造船技報，21-4（昭 35-11)，13.

（6）清水・は加，漁船研究技報，12（昭 33-10），45.

（7）清水, 内燃機関，2-12（昭 38-6）, 71.

(8) B. Olsson, The Motor Ship, 37-433 (1956-6), 93.

(9) 松水 - は办, 機械学会第 41 期全国大会講演会前刷集, No. 98 (昭38-10), 99.

（10）たとえば，清水・はか，漁船研究技報，10（昭 32-4），1.

(11）草間，漁船研究技報，18-1 (昭 38-8), 1.

（12）清水・はか, 機械学会誌, 66-531 (昭 38-4), 578.

\section{=ュ-ス 放射性同位元素による火事の早期発見}

どんな大火事でも，その初期においては，たいてい ごく少量の物質が比較的ゆっくりと燃え始めることか らスタートするものである.したがうてこのときに気 がつい゙て消しさえすれば，その損害はほとんど無視で きるくらい小さなものである. 従来この早期発茪のた めに, 空気の温度上昇を検出したり，空気中の光の透 過度の煙による変化を検出したりなどすることによる 火災検知器はあったが，いずれも不十分なものであっ た. 最近イギリスの Minerva Detector 社が研究製作 した放射性同位元素を利用した検知装置は，現在では 火災初期の微量の燃焼生成物たるわずかな烇の検出の 泪的に対して，最も満足すべきものであるということ む, 火災保険各社と消防当局との間で意見が一致し た.

この装置は, ㅅ...線を出す放射性同位元素（ラジウム 226 あるいはアメリシウム 241）圭内蔵した電離そう とその付属回路とより成っている. もし煙がその電瀖
そう内に侵入してくると，電離そう内の空気中に $\alpha$ 線 により電離して生成されたイオンが煙の粒子に付着す る. 煙の粒子は空気のイオンに比べてはるかに重量が 大きいので，電離そう電極に移動する早さが非常にお そい.したがってその途中で,反対符号のイオンと出会 って中和する確率が大きい. その結果, 煙がはいって くると電離電流が大幅に減少する.したがってたとえ ば電離そう内の空気中に 1 万分の 1 の微量の煙がはい

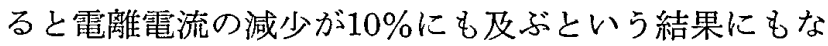
る.このため非常に微量でとうてい目に見えないよう な煙の存在でも検出できる.そしてこれによって直ち に警報を発することができる。これはすでに“Minerva", “Pyr-a-larm”, および Cerberusなどの商品 名で発売されている.

(Instr. Pract., Vol. 20, No. 12, 1966, p. 975 978) （科学技術文献速報より転載）

\section{アメリカは電カブーム}

エジソン電気協会の電力調查委員会は, 8 月末にア メリカの電力産業の爆発的な成長が見られることを中 間報告で発表した.

おもな数值は次のとおりである.

・本年の第 2 四半期に発注されたタービン発電機の総 容量は $9000 \mathrm{MW}$ におよび, これは昨年の最終四半期 の記録よりわずかに低い.

・本年の最初の 6 箇月間に発注された電力用変圧器は 泎年同期よりも $14 \%$ 増加した。

·本年の全発電量は昨年よりも $8 \%$ 増加すると期待さ 丸る. 昨年の増加率は $7.4 \%$ であった。

なおここ報告では言及されていないが，がいし類 の出荷も大幅に増加し，本年最初の 6 箇月で昨年同期 の $33 \%$ を上回るとみられている. そして年間では昨 年の記録 5300 万ドルの $13 \%$ 増が期待されている.

本年の半ばにおいては, $89000 \mathrm{MW}$ の 518 ユニット が発注または本年中に運転開始の予定であるがそのう
ち, $85.5 \%$ が蒸気タービンユニットで, $14.2 \%$ が水 力（揚水を含む）である. 355 の蒸気タービンユニッ トのうち, $12100 \mathrm{MW}$ の 22 ユニットは原子力による ものである. 163 の水力ユニットのうち，36.2\%に当 たる $12600 \mathrm{MW}$ の 46 ユニットは揚水発電である.

電力用変圧器もまた記録を更新した. 現在 172646 $\mathrm{MW}$ が発注または出荷されており，各クラスの在庫 生産も最高の記録を作り，1965年の前半の記録を14\% 上回っている.そのうち，国内向けが $98.4 \%$, 外国 向けが $1.6 \%$ である.

ボイラの発注状況も，本年の第 1 四半期に比べて第 2 四半期は $65.7 \%$ 増となっている. 本年の計画では 1965 年の $29.8 \%$ 増の 1 億 6950 万 $\mathrm{lb} / \mathrm{h}$ の生産高が見 込まれている. 1967 年は 1 億 4810 万 $\mathrm{lb} / \mathrm{h}$ が計画さ れている.

(Elec. World, Vol. 166, No. 10, 1966; p. 29 30) (科学技術文献速報より転載) 